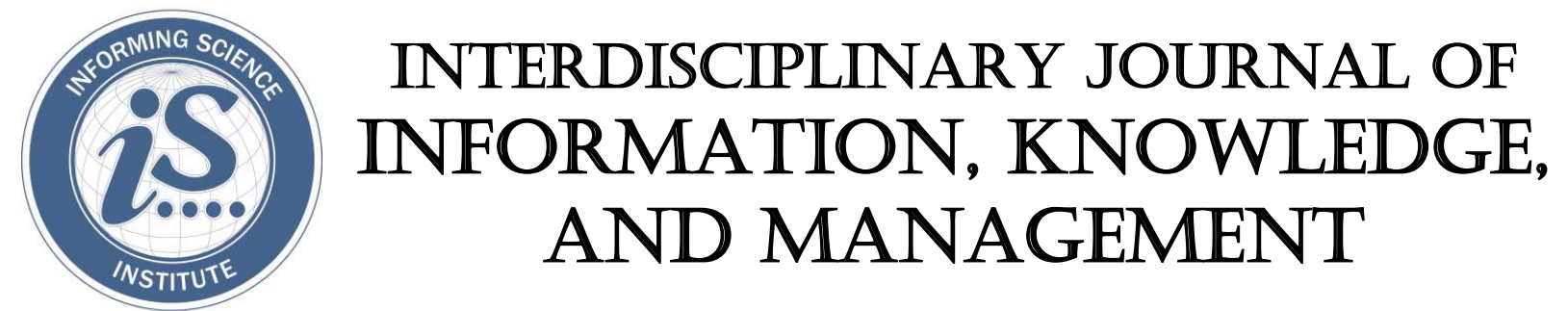

Volume 11, 2016

Editors-in-Chief: Mike Hart, Kevin Johnston, and Elsje Scott, University of Cape Town, South Africa

Managing Editor: Eli Cohen, Informing Science Institute, USA

Publisher: Elizabeth Boyd; Informing Science Institute, USA

Editors:

Jeffrey Alstete, Iona College (USA)

Tharrenos Bratitsis, University of Western Macedonia (Greece)

Harry Tomas Fulgencio, Leiden University (Netherlands)

Salah Kabanda, University of Cape Town (South Africa)

Jörg Lässig, University of Applied Sciences Zittau/Görlitz (Germany)

Nelson K. Y. Leung, RMIT International University (Vietnam)

Geoffrey Z. Liu, San Jose State University (USA)

June Lu, University of Houston-Victoria (USA)

Rajeev Manhas, Baba Farid University of Health Sciences (India)

Jayanthi Ranjan, Institute of Management Technology (India)

Muzafer H. Saracevic, University of Novi Pazar (Serbia and Montenegro)

Christine Nya Ling Tan, Multimedia University (Malaysia)

Maureen Tanner, University of Cape Town (South Africa)

Michael Tomblin, Marshall University (USA)

Dale Trott, Central Queensland University (Australia)

John K. Webber, University of Phoenix (USA)

Ewa Ziemba, University of Economics in Katowice (Poland)

The mission of the Interdisciplinary Journal of Information, Knowledge, and Management (IJIKM) is to provide readers with the widest possible coverage of the use of information and technology to effectively create, apply, and communicate knowledge in organizations. In addition to manuscripts that center on knowledge acquisition and sharing, agent-based systems, neural networks, genetic algorithms, learning systems, and natural language processing, we welcome manuscripts on a wide range of topics relating to the organizational use and management of information and technology.

IJIKM publishes scholarly conceptual, theoretical and empirical manuscripts on the use of information technology to enhance organizational performance. Submissions to the journal should be readable and understandable by a wide audience. Manuscripts should therefore also focus on practical application or illustration of the issues covered, rather than merely providing a mathematical or technical coverage, which would be more suitable for a specialist journal.

All manuscripts are submitted and reviewed electronically. We provide our published authors with both a quality print publication and the widespread readership that comes from publishing all manuscripts online within a few weeks of acceptance. This approach ensures that published works are read and cited by the widest possible audience. 
IJIKM is an academically peer reviewed Journal. All submissions are blind refereed by three or more peers. IJIKM is published in print by subscription and its articles also appear online free of charge on the web site http://ijikm.org

IJIKM is listed in Cabell's Directory of Publishing Opportunities in Educational Technology \& Library Science, Cabell's Directory of Publishing Opportunities in Management, Directory of Open Access Journals (DOAJ), EBSCO, Index of Information System Journals, Ulrichs.

(CC BY-NC 4.0) The articles in this journal are licensed under a Creative Commons AttributionNonCommercial 4.0 International License. When you copy and redistribute this paper in full or in part, you need to provide proper attribution to it to ensure that others can later locate this work (and to ensure that others do not accuse you of plagiarism). You may (and we encourage you to) adapt, remix, transform, and build upon the material for any non-commercial purposes. This license does not permit you to use this material for commercial purposes.

ISSN Print 1555-1229, Online 1555-1237 ISBN: 978-1-68110-011-1

\footnotetext{
Published by the Informing Science Institute 131 Brookhill Ct., Santa Rosa, California USA phone: +1-707-537-2211; fax: +1-815-301-6785 http://informingscience.org
} 


\section{IJIKM Volume 11, 2016 - Table of Contents}

A Conceptual Model for the Creation of a Process-Oriented Knowledge Map (POK-Map)

and Implementation in an Electric Power Distribution Company

Babak Teimourpour, Vahid Eslami, Maghsoud Mohammadi, and

Milad Padidarfard

Behavioral Aspects of ERP Implementation: A Conceptual Review

Prokreeti Mitra and Sasmita Mishra

The Effect of Perceived Expected Satisfaction with Electronic Health Records Availability on Expected Satisfaction with Electronic Health Records Portability in a Multi-Stakeholder Environment

Karoly Bozan and Pratim Datta

Doing the Organizational Tango: Symbiotic Relationship between Formal and Informal Organizational Structures for an Agile Organization

Irena Ali

External Variables as Antecedents of Users Perception in Virtual Library Usage

Olusola I. Akinbobola and Akinniyi A. Adeleke

Factors Affecting the Adoption and Usage of ICTs within Polish Households

Ewa Ziemba

Facilitating mCommerce Growth in Nigeria through mMoney Usage: A Preliminary Analysis

Christian Nedu Osakwe and Titus Chukwuemezie Okeke 115-139

Management of Knowledge, Innovation and Performance in SMEs

Luis Enrique Valdez-Juárez, Domingo García-Pérez de Lema, and

Gonzalo Maldonado-Guzmán

Knowledge Management and Problem Solving in Real Time: The Role of Swarm Intelligence Chris William Callaghan

Analogical Thinking for Generation of Innovative Ideas: An Exploratory Study of Influential Factors

Eunyoung Kim and Hideyuki Horii

Towards A Methodology for the Pre-Stage of Implementing a Reengineering Project

Shahram Nasiri, Mohammad Javad Nasiri, and Asiyeh Sa'adati Azar

Innovation Capability: A Systematic Review and Research Agenda

Faisal Iddris

A Multi-task Principal Agent Model for Knowledge Contribution of Enterprise Staff

Cheng-yi Le

Aspects of Digital Forensics in South Africa

Alastair Irons and Jacques Ophoff

Challenges of Knowledge and Information Management during New Product Introduction:

Experiences from a Finnish Multinational Company

Eeva Järvenpää, Miia-Johanna Kopra, and Minna Lanz 285-308 
Does Usability Matter? An Analysis of the Impact of Usability on Technology Acceptance in ERP Settings

Brenda Scholtz, Imran Mahmud, and T. Ramayah 309-330

Knowledge Management in Nigerian Universities: A Conceptual Model

Adebowale Ojo

Intention to Use and Satisfaction of e-Learning for Training in the Corporate Context

Maxine Esterhuyse, Brenda Scholtz, and Danie Venter 347-365 